\title{
EFEK KONSUMSI BERBAGAI JENIS MINYAK GORENG TERHADAP KETEBALAN TUNIKA INTIMA PADA TIKUS JANTAN STRAIN WISTAR
}

\author{
Tetes Wahyu Witradharma
}

Poltekkes Bengkulu, Jurusan Gizi, Jl. Indragiri No.3 Bengkulu, Email: teteswahyu@gmail.com

\begin{abstract}
CVD has close relationship with nutrition and food. But the results of another study did not support the close relationship between saturated fat intake with blood lipid levels and risk of CVD. The aim is to determine the effect of various types of fried oil consumption to the thickness of tunica intima in male rats of wistar strain. This study was an experimental research. The sample were 25 rats based on inclusion and exclusion criteria. Treatment groups were separated and each given long chain saturated fatty acid (LCSFA) cow fat, medium chain saturated fatty acid (MCSFA) VCO, polyunsaturated fatty acid (PUFA) corn oil and monounsaturated fatty acid (MUFA) olive oil orally $2.5 \mathrm{ml} /$ day for 2 months. Data were obtained include the sample characteristics and thickness of tunica intima. The highest mean of tunica intima thickness was corn oil $16385,61 \pm 1715,79 \mathrm{~nm}$ and the lowest olive oil $12075,97 \pm 2464,34 \mathrm{~nm}(\mathrm{p}=0,033)$. This study shows that the harmful effects of SFA and the protective effects of UFA to the thickness of tunica intima need to be corrected because not all SFA is bad and UFA is good for health. It is therefore recommended to inform about foods are beneficial for health.
\end{abstract}

\begin{abstract}
Abstrak : Penyakit kardiovaskular mempunyai hubungan yang erat dengan nutrisi dan makanan. Tetapi hasil penelitian yang lain tidak mendukung adanya hubungan antara asupan lemak jenuh dengan kadar lemak darah dan risiko PKV. Tujuan penelitian untuk mengetahui efek konsumsi berbagai jenis minyak goreng terhadap ketebalan tunika intima pada tikus jantan strain wistar. Penelitian ini merupakan penelitian eksperimental. Sampel berjumlah 25 ekor tikus berdasarkan kriteria inklusi dan ekslusi. Kelompok perlakuan dikandangkan secara terpisah dan masing-masing diberikan asam lemak jenuh rantai panjang (ALJP) lemak sapi, asam lemak jenuh rantai sedang (ALJS) VCO, asam lemak tidak jenuh ganda (ALTJG) minyak jagung dan asam lemak tidak jenuh tunggal (ALTJT) minyak zaitun secara oral sebanyak 2,5 $\mathrm{ml} / \mathrm{hr}$ selama 2 bulan. Data yang diperoleh meliputi karakteristik sampel dan ketebalan tunika intima. Rerata ketebalan tunika intima tertinggi minyak jagung $16385,61 \pm 1715,79 \mathrm{~nm}$ dan terendah minyak zaitun $12075,97 \pm 2464,34 \mathrm{~nm}(\mathrm{p}=0,033)$. Penelitian ini menunjukkan bahwa efek berbahaya dari asam lemak jenuh (ALJ) dan efek protektif dari asam lemak tidak jenuh (ALTJ) terhadap indikator kejadian aterogenesis perlu ditinjau karena tidak semua ALJ jelek dan ALTJ baik untuk kesehatan. Oleh karena itu perlu dilakukan promosi gizi dan kesehatan tentang bahan makanan yang baik bagi kesehatan.
\end{abstract}

Kata Kunci : minyak goreng, aterogenesis, tunika intima, tikus

Prevalensi PKV meningkat sangat pesat. Data yang diperoleh dari WHO di dalam Mortality Country Fact Sheet menunjukkan bahwa penyakit jantung iskemik menempati urutan pertama 10 besar penyebab kematian di Indonesia sebesar 14\% pada tahun 2002 (WHO, 2006).

PKV mempunyai hubungan yang erat dengan zat gizi dan makanan. Hipotesis "makanan-jantung" atau diet-heart hypothesis menerangkan bahwa adanya hubungan antara makanan dengan penyakit jantung. Dalam hipotesis itu diterangkan bahwa konsumsi makanan mengandung lemak jenuh dan kolesterol akan menyebabkan resiko terjadinya penyakit jantung. Peningkatan konsumsi lemak jenuh pada beberapa kelompok masyarakat berakibat peningkatan konsentrasi kolesterol dalam darah dan juga meningkatkan kematian akibat PJK (Kromhout, et., al., 2000).

Di Indonesia, khususnya daerah perkotaan telah mengalami perubahan gaya hidup (life style) khususnya pola makan. Adanya perbaikan status ekonomi dan intervensi budaya barat, komposisi makanan 
sehari-hari pun berubah menjadi tinggi karbohidrat khususnya karbohidrat sederhana, tinggi lemak terutama lemak hewani namun rendah kandungan seratnya selain aktifitas yang menurun sehingga berperan besar dalam peningkatan prevalensi penyakit vaskuler aterosklerotik khususnya penyakit jantung koroner di Indonesia (Dinarto, 2000).

Aplikasi penggunaan asam lemak dalam kehidupan sehari-hari salah satunya adalah pemakaian minyak di dalam proses pengolahan makanan. Minyak yang digunakan berbeda di beberapa tempat, misalnya penggunaan minyak jagung di masyarakat barat khususnya Amerika, minyak zaitun pada masyarakat Timur Tengah, minyak kelapa pada masyarakat Indonesia khususnya Padang dan lemak sapi pada sebagian masyarakat Malaysia. Minyak yang digunakan tersebut tentu saja memiliki komposisi tidak hanya asam lemak jenuh atau tidak jenuh saja tetapi merupakan kombinasi antara keduanya dan juga zat gizi lainnya. Komposisi yang beragam inilah yang menarik untuk diungkap, karena tiap asam lemak akan berinteraksi satu sama lain yang akhirnya akan berimplikasi klinis terhadap ketebalan tunika intima yang merupakan salah satu indikator kejadian aterogenesis dan PKV selanjutnya.

\section{BAHAN DAN CARA KERJA}

Penelitian dilakukan di Laboratorium Biokimia FMIPA IPB Bogor, Laboratorium Farmakologi dan Fisiologi Fakultas Farmasi Universitas Andalas untuk persiapan dan pengkondisian bahan dan sampel serta dilanjutkan ke tahap intervensi dan perlakuan. Pengambilan jaringan aorta sampel dilakukan di Laboratorium Farmasi Fakultas Farmasi Universitas Andalas. Sedangkan untuk pemeriksaan histopatologi jaringan aorta dilakukan di Laboratorium Patologi Anatomi FK Universitas Andalas.
Penelitian ini merupakan penelitian eksperimental. Sampel penelitian merupakan bagian dari populasi penelitian. Sampel penelitian yang digunakan adalah tikus jantan jenis Rattus novergicus Strain Wistar yang banyak digunakan dalam berbagai penelitian berjumlah 25 ekor yang didapatkan dengan menggunakan rumus Abo Crombi dengan mempertimbangkan droup out sebesar 10-20\%. Adapun kriteria inklusi pada penelitian ini yaitu: tikus berjenis kelamin jantan, berumur \pm 3 bulan, dan memiliki berat 100-150 gram. Sedangkan kriteria eksklusi pada penelitian ini, yaitu: tikus yang tidak mau makan dan mengalami penurunan keadaan fisik atau mati. Kelompok perlakuan dikandangkan secara terpisah dan masing-masing diberikan asam lemak jenuh rantai panjang (ALJP) lemak sapi, asam lemak jenuh rantai sedang (ALJS) VCO, asam lemak tidak jenuh ganda (ALTJG) minyak jagung dan asam lemak tidak jenuh tunggal (ALTJT) minyak zaitun secara oral sebanyak 2,5 $\mathrm{ml} / \mathrm{hr}$ selama 2 bulan.

Data disajikan dalam bentuk analisis univariat untuk karakteristik sampel. Selanjutnya dilakukan analisis bivariat untuk mengetahui ada tidaknya pengaruh konsumsi lemak sapi, VCO, minyak jagung dan zaitun terhadap ketebalan tunika intima pada tikus jantan strain wistar, digunakan analisis anova one way dengan derajat kepercayaan $95 \%$. Kemudian untuk mengetahui letak perbedaan lebih lanjut digunakan uji post hoc bonferoni. Analisis data ini diolah dengan menggunakan perangkat lunak komputer .

\section{HASIL}

\section{Analisis Univariat}

Karakteristik sampel penelitian dari kelompok kontrol dan perlakuan, meliputi jumlah, umur, jenis kelamin dan berat badan awal dapat dilihat pada tabel 1 . 
Tabel 1. Karakteristik Sampel Penelitian

\begin{tabular}{|c|c|c|c|c|c|}
\hline \multirow{2}{*}{ Karakteristik } & \multicolumn{5}{|c|}{ Kelompok Perlakuan } \\
\hline & $\mathrm{K}-$ & $\mathrm{P} 1$ & P2 & P3 & P4 \\
\hline Jumlah (n) & 5 & 5 & 5 & 5 & 5 \\
\hline Umur (bulan) & $3-3.5$ & $3-3.5$ & $3-3.5$ & $3-3.5$ & $3-3.5$ \\
\hline Jenis Kelamin & Jantan & Jantan & Jantan & Jantan & Jantan \\
\hline
\end{tabular}

Pada tabel tersebut dapat terlihat bahwa sampel pada penelitian ini telah ho- mogen dan memenuhi kriteria inklusi yang ditetapkan sebelumnya.

Tabel 2. Perbedaan Rerata Ketebalan Tunika Intima (nm) pada Berbagai Kelompok

\begin{tabular}{ccc}
\hline Kelompok & Ketebalan Tunika Intima $(\mathrm{nm})($ mean \pm SD) & $\mathrm{p}$ \\
\hline K - & $13551,89 \pm 1291,88$ \\
P 1 & $16049,68 \pm 3037,79$ & $0,033^{*}$ \\
P 2 & $13552,42 \pm 2455,78$ & \\
P 3 & $16385,61 \pm 1715,79$ & \\
P 4 & $12075,97 \pm 2464,34$ & \\
\hline
\end{tabular}

Keterangan : $\quad$ K- = Diet Normal, P1 = Diet Normal + Lemak Sapi 2,5 ml/hr, P2 = Diet Normal + VCO 2,5 ml/hr, P3 = Diet Normal + Minyak Jagung 2,5 ml/hr, P4 = Diet Normal + Minyak Zaitun 2,5 ml/hr, ${ }^{*} \mathrm{p}<0,05$ : signifikan

Dari tabel 2 dapat diketahui bahwa ada perbedaan rerata ketebalan tunika intima di antara kelompok kontrol dan perlakuan $(p<0,05)$. Pada tabel tersebut dapat terlihat bahwa minyak jagung memiliki ketebalan tunika intima tertinggi sedangkan minyak zaitun memiliki ketebalan tunika intima terendah. Adapun analisis lebih lanjut tidak menunjukkan adanya hubungan yang signifikan di antara berbagai kelompok perlakuan dan kontrol penelitian.

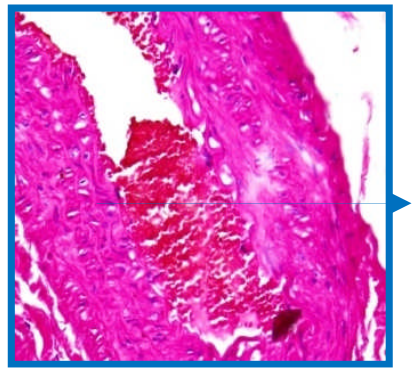

$\mathrm{K}-$

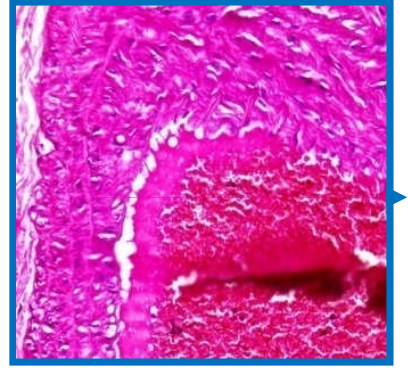

P1

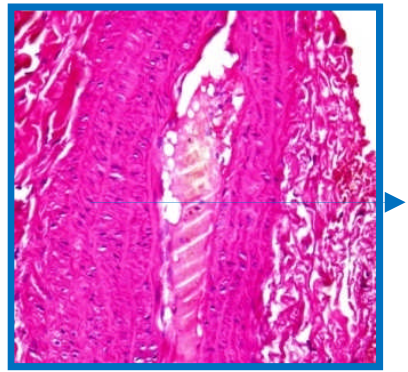

P2

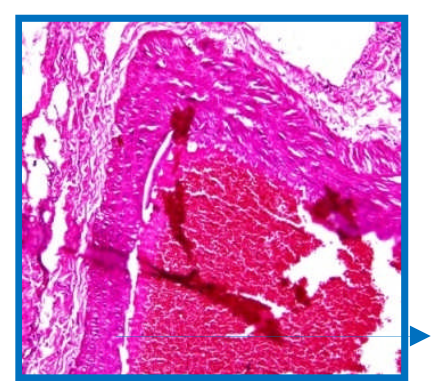

P3

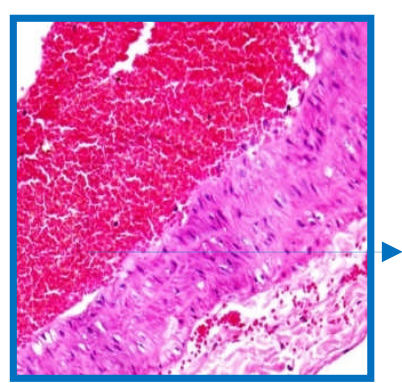

P4

Gampar 1 : nası rengecatan Aorta Abdomınaıs paaa seroagaı nelompok

Keterangan : K- $=$ Diet Normal, P1 $=$ Diet Normal + Lemak Sapi $2,5 \mathrm{ml} / \mathrm{hr}, \mathrm{P} 2=$ Diet Normal $+\mathrm{VCO} 2,5 \mathrm{ml} / \mathrm{hr}$, P3 = Diet Normal + Minyak Jagung 2,5 ml/hr, P4 = Diet Normal + Minyak Zaitun 2,5 ml/hr; $1=$ Tunika Intima 
Deskripsi mikroskopis dengan perbesaran 100 dan 400 kali pada kelompok kontrol dan perlakuan dapat dilihat pada gambar 1. Dari gambar tersebut dapat dilihat bahwa ketebalan tunika intima pada kelompok kontrol dan VCO memiliki ukuran yang hampir sama. Demikian juga antara lemak sapi dan minyak jagung memiliki ketebalan tunika intima yang tidak jauh berbeda. Sedangkan pada minyak zaitun menunjukkan ketebalan tunika intima yang lebih kecil dibandingkan kontrol.

\section{PEMBAHASAN}

Hasil penelitian ini menunjukkan adanya perbedaan rerata ketebalan tunika intima pada berbagai kelompok. Rerata ketebalan tunika intima tertinggi terdapat pada kelompok yang mengkonsumsi minyak jagung. Penggunaan minyak jagung sebagai salah satu bahan pada penelitian ini karena merupakan sumber asam lemak tidak jenuh ganda (ALTJG) asam linoleat (C18 :2; 9,12). Rerata ketebalan tunika intima dengan nilai yang sedikit lebih rendah ternyata didapatkan pada kelompok yang mengkonsumsi lemak sapi. Lemak sapi dipilih sebagai salah satu bahan pada penelitian ini karena merupakan sumber asam lemak jenuh rantai panjang (ALJP) asam palmitat (C16:0). Rerata ketebalan tunika intima dengan nilai yang lebih rendah, selanjutnya ditemukan pada kelompok yang mengkonsumsi VCO yang merupakan sumber asam lemak jenuh rantai sedang (ALJS) asam laurat (C12:0).

Penelitian ini juga membuktikan ternyata rerata ketebalan tunika intima antara kelompok yang mengkonsumsi VCO menunjukkan nilai rerata yang hampir sama dengan kelompok kontrol yang hanya mengkonsumsi diet normal saja. Hal ini menunjukkan bahwa konsumsi VCO tidak menyebabkan ketebalan pada tunika intima. Hasil yang sama juga ditunjukkan pada beberapa penelitian yang telah di- lakukan sebelumnya. Penelitian yang dilakukan oleh Ariana dan Udadi, 2006 telah membuktikan bahwa pemberian VCO yang banyak mengandung asam lemak jenuh (ALJ) asam laurat (C12:0) dapat menurunkan ketebalan dinding aorta abdominalis secara bermakna pada tikus jantan jenis Wistar setelah diinduksi aterogenesis. Asam lemak jenuh rantai sedang (MCFA) asam laurat (C12:0) yang merupakan komposisi terbesar di dalam VCO dimetabolisme dengan cara yang berbeda dibandingkan asam lemak jenuh yang lain. Kelarutannya yang sangat tinggi di dalam air serta kebutuhan enzim pencernaan yang lebih sedikit, membuatnya mudah masuk ke dalam hati melalui vena tanpa harus melalui sirkulasi limpa dan sistemik serta dengan cepat dibakar sebagai energi. Hal ini menyebabkan peningkatan metabolisme di dalam tubuh sehingga asam lemak tidak diubah menjadi lemak yang terdeposit dan kolesterol di dalam tubuh. Penurunan deposit lemak dalam tubuh dapat menurunkan kolesterol LDL dan meningkatkan kolesterol HDL yang memilki hubungan erat dengan resiko kejadian aterosklerosis (Lipoeto, 2006).

Rerata ketebalan tunika intima dengan nilai terendah didapatkan pada kelompok yang mengkonsumsi minyak zaitun yang merupakan sumber asam lemak tidak jenuh tunggal (ALTJT) asam oleat $(\mathrm{C} 18: 2 ; 9,12)$. Hasil penelitian ini menunjukkan bahwa nilai rerata ketebalan tunika intima yang didapatkan pada kelompok yang mengkonsumsi minyak zaitun sedikit lebih rendah daripada kelompok kontrol. Oleh karena itu, bisa dijelaskan bahwa konsumsi minyak zaitun terhadap ketebalan tunika intima memiliki pengaruh yang lebih baik dibandingkan minyak jagung, lemak sapi dan VCO sehingga minyak zaitun ini dapat digunakan sebagai salah satu alternatif functional food di dalam pengaturan pola makan khususnya pada pasien dengan yang 
terdiagnosa penyakit kardiovaskular. Di samping itu penggunaan minyak zaitun ini dapat digunakan sebagai alternatif preventif kejadian aterogenesis. Beberapa hasil yang sama juga ditemukan pada beberapa penelitian yang lain. Konsumsi $\omega 9$ asam oleat yang banyak terdapat di dalam minyak zaitun dan ikan bermanfaat untuk meningkatkan kadar NO dan menurunkan mobilisasi asam arakhidonat dan produksi $\mathrm{PGE}_{2}$ (Moreno et., al., 2001) serta melindungi LDL sehingga tidak teroksidasi (Ramirez-Tortosa et., al., 1999; Aditya, 2010). Di samping itu, asam oleat akan menghambat produksi $\Delta 6$ desaturase sehingga menurunkan konversi asam linoleat menjadi asam arakhidonat yang akan berbungsi sebagai anti inflamasi (Moreno et., al., 2001). Lebih lanjut, asam oleat akan mencegah proses LDL menjadi teroksidasi (Fito et al., 2007). Pada penelitian lain juga dijelaskan bahwa meskipun ALTJ meningkatkan sintesa kolesterol tetapi mereka juga meningkatkan jumlah reseptor LDL di hati dan mekanisme turn over LDL (Fernandez and Kristy, 2005).

Berbeda dengan kelompok yang mengkonsumsi minyak zaitun, kelompok yang mengkonsumsi minyak jagung, walaupun sama-sama ALTJ tetapi memiliki pengaruh yang berbeda terhadap ketebalan tunika intima. Minyak jagung memiliki komposisi asam lemak yang beragam dengan asam linoleat $(\mathrm{C} 18: 2 ; 9,12)$. Konsumsi asam linoleat dapat menurunkan LDL dan HDL darah, mudah teroksidasi sehingga menjadi sangat aterogenik (Sies, et., al., 2005; Mozzaffarian, et., al.,2006) serta merangsang pembentukan inflamasi pada endotel vaskular (Toborek et., al., 2002). Di samping itu, konsumsi asam linoleat akan meningkatkan kadar asam arakhidonat plasma sehingga akan meningkatkan $\operatorname{cox}_{2}$ dan lipoxigenase yang selanjutnya akan membentuk $\mathrm{PGE}_{2}$ dan $\mathrm{LTB}_{4}$ yang merupakan marker inflamasi (Calder, 2006; Murray, 2009). Hal ini menunjukkan bahwa inflamasi merupakan salah satu faktor yang penting yang dapat digunakan sebagai indikator kejadian aterogenesis yang sedang terjadi. Oleh karena itu, apabila komponen inflamasi berbahaya bagi arteri secara selektif dapat dimodifikasi dengan mempertahankan keutuhan aspek protektifnya, maka bisa tercipta pandangan baru dalam diagnosis dan manajemen penyakit pada $50 \%$ pasien kardiovaskuler yang tidak mengalami hiperkolesterolemia (Prasetyo dkk., 2006).

\section{KESIMPULAN}

Minyak jagung (ALTJG) lebih menebalkan tunika intima dibandingkan lemak sapi (ALJP) sedangkan minyak zaitun (ALTJT) lebih menipiskan tunika intima. Adapun VCO (ALJS) tidak menebalkan dan menipiskan tunika intima.

Penelitian ini menunjukkan bahwa efek berbahaya dari ALJ dan efek protektif dari ALTJ terhadap indikator kejadian aterogenesis perlu ditinjau kembali karena tidak semua ALJ jelek dan ALTJ baik untuk kesehatan. Oleh karena itu perlu dilakukan promosi gizi dan kesehatan tentang bahan makanan yang baik bagi kesehatan. Hasil penelitian ini juga menunjukkan bahwa perlu dilakukan penelitian yang berorientasi pada efek kuratif dengan melakukan induksi aterogenesis pada hewan percobaan dengan memodifikasi komposisi makanan yang diberikan ataupun bahan yang lain (adrenalin) kemudian diberikan intervensi yang sama dengan dosis dan waktu yang lebih lama. Selanjutnya hasil penelitian ini menunjukkan bahwa perlu dilakukan penelitian lebih lanjut yang mengkaji secara komprehensif dengan mengidentifikasi berbagai faktor resiko dengan menggunakan indikator-indikator kejadian aterogenis yang lebih banyak sehingga akan didapatkan pemahaman yang lebih baik tentang mekanisme aterogenesis ini serta akan memunculkan paradigma baru penatalaksanaan penyakit kardiovaskular di masa mendatang. 


\section{DAFTAR KEPUSTAKAAN}

WHO, 2006. Mortality Country Fact Sheet 2006. World Health Statistics

Kromhout, D., Bennie B., Edith F., Alessandro M., Aulikki N., 2000. Saturated Fat, Vitamin C and Smoking Predict Long Term Population All Cause Mortality Rates in the Seven Countries Study. International Journal of Epidemiology

Dinarto, M., 2000. Nutrisi pada Penyakit Vaskuler Aterosklerotik. PDGMI

Simopoulos, A.P., 2008. Minireview. The Importance of the Omega 6/Omega 3 Fatty Acid Ratio in Cardiovascular Disease and Other Chronic Diseases. Society for Experimental Biology and Medicine

Hu, F.B., Meir J.S., JoAnn E.M., Alberto A., Graham A.C., Frank E.S. et al., 1999. Dietary Saturated Fats and Their Food Sources in Relation to the Risk of Coronary Heart Disease in Women. American Journal of Clinical Nutrition

Khosla, P. and K.C. Hayes, 1992. Comparison Between The Effect of Dietary Saturated (16:0), monounsaturated (18:1) and Polyunsaturated (18:2) Fatty Acid on Plasma Lipoprotein Metabolism in Cebus and Rhesus Monkeys Fed Cholesterol Free Diet. American Journal of Clinical Nutrition

Sundram, K., K.C. Hayes, Othman H.S., 1994. Dietary Palmitic Acid Results in Lower Serum Cholesterol than Does a Lauric Myristic Acid Combination in Normolipemic Humans. American Journal of Clinical Nutrition

Katan, M.B., Peter L.Z., Ronald P.M., 1994. Effects of Fats and Fatty Acids on Blood Lipids in Humans: an Overview. American Journal of Clinical Nutrition

Fernandez M.L. and Kristy L.W., 2005. Mechanisms by which Dietary Fatty Acids Modulate Plasma Lipids. Journal of Nutrition

Arab, L., 2003. Biomarkers of Fat and Fatty Acid Intake. Journal of Nutrition

Grundy, S.M. and Denke M.A., 1990. Dietary Influences on Serum Lipids and Lipoproteins. Journal of Lipid Research

Aditya, M., 2010. Pengaruh Minyak Zaitun Murni Ekstra (Extra Virgin Coconut Oil) terhadap Kadar Kolesterol Total Tikus Putih (Rattus novergicus) yang Dikondisikan Hiperkolesterolemia. Surabaya: FKH UNAIR

Almario, R.U., Vonghavaravat V., W'ong R., Kasim-Karakas S.E., 2001. Effects of Walnut Consumption on Plasma Fatty, Acids and Lipoprotein in Combined Hyperlipidemia. American Journal of Clinical Nutrition

Ariana, Y. dan Udadi S., 2006. Pengaruh Pemberian Virgin Coconut Oil terhadap Ketebalan Dinding Aorta Abdominalis Tikus
Wistar Sesudah Diinduksi Aterogenesis. Semarang: FK UNDIP

Calder, P.C., 2006a. Long Chain Polyunsaturated Fatty Acids and Inflammation. Scandinavian Journal of Food and Nutrition

Dayrit, C.S., 2003. Coconut Oil: Atherogenic or Not?. Philippine Journal of Cardiology

De Caterina, R., James K.L., Peter L., 2000. Fatty Acid Modulation of Endothelial Activation. American Journal of Clinical Nutrition

De Lorgeril, Salen P., Martin J.L., Monjaud I., Delaye J., Mamelle N., 1999. Mediterranean Diet, Traditional Risk Factors and The Rate of Cardiovascular Complications After Myocardial Infarction: Final Report of The Lyon Diet Heart Study. Circulation

De Roos, Nicole M., Evert G. Schouten, Martijn B. Katan, 2001. Consumption of a Solid Fat Rich in Lauric Results in a More Favorable Serum Lipid Profile in Healthy Men and Women than Consumption of a Solid Fat Rich in Trans Fatty Acids. Journal of Nutrition

Dorfman, S.E., Shu Wang, Sonia V., Matti J., Alice H.L., 2005. Dietary Fatty Acids and Cholesterol Differentially Modulate HDL Cholesterol Metabolism in Golden-Syrian Hamsters. Journal of Nutrition

Fito, M., M. Cladellas, R. de la Torre, J. Marti, D. Munoz, H. Schroder et al., 2008. Anti Inflammatory Effect of Virgin Olive Oil in Stable Coronary Disease Patients: A Randomized, Crossover, Controlled Trial. European Journal of Clinical Nutrition

Garg, A., 1998. High Monounsaturated Fat Diets for Patients with Diabetes Mellitus: a Meta Analysis. American Journal of Clinical Nutrition

Hodgson, L., C.M. Skeaff, W-A.H. Chisholm, 2001. The Effect of Replacing Dietary Saturated Fat with Polyunsaturated or Monounsaturated Fat on Plasma Lipids in Free Living Young Adults. European Journal of Clinical Nutrition

James, M.J., Robert A.G., Leslie G.C., 2000. Dietary Polyunsaturated Fatty Acids and Inflammatory Mediator Production. American Journal of Clinical Nutrition

Krisnawati, D., 2007. Pengaruh Pemberian Virgin Coconut Oil (VCO) terhadap Jumlah Leukosit Darah Tepi pada Tikus Wistar Jantan yang Dipapar Staphylococus aureus. Perpustakaan UNJEM.

Lipoeto, N.I., 2006. Zat Gizi dan Makanan pada Penyakit Kardiovaskuler. Padang: Andalas University Press.

Mensink, R.P., 1994. Dietary Monounsaturated Fatty Acids and Serum Liprotein Levels in Healthy Subjects. Atherosclerosis 
Mensink, R.P., Peter L. Zock, Arnold D.M. Kester, Martijn B. Katan, 2003. Effects of Dietary Fatty Acids and Carbohydrates on The Ratio of Serum Total to HDL Cholesterol and on Serum Lipids and Apolipoprotein: a Meta Analysis of 60 Controlled Trials. American Journal of Clinical Nutrition

Mensink, R.P., Peter L. Zock, Arnold D.M. Kester, Martijn B. Katan, 2003. Effects of Dietary Fatty Acids and Carbohydrates on The Ratio of Serum Total to HDL Cholesterol and on Serum Lipids and Apolipoprotein: a Meta Analysis of 60 Controlled Trials. American Journal of Clinical Nutrition

Moreno, J.J., T. Carbonelli, T. Sanchez, S. Miret, Maria T.M., 2001. Olive Oil Decreases Both Oxidative Stress and The Production of Arachidonic Acid Metabolites by The Prostaglandin G/H Synthase Pathway in Rat Macrophages. Journal of Nutrition

Mozzafarian, D., Martijn B.K., Alberto A., Meir J.S., Walter C.W., 2006. Trans Fatty Acids and Cardiovascular Disease. New England Journal of Medicine

Nugraha, G.I., 2004. Profil Lipid dan Apoliprotein A-I serta Faktor-faktor yang Berhubungan pada Perajin Minyak Kelapa di Jawa Barat. Tesis. Universitas Indonesia, Jakarta.

Prasetyo, A., dan Sadhana, U., 2006. Aspek Seluler dan Molekuler Aterosklerosis. Media Medika Muda
Rahmawansa, S., 2009. Dislipidemia sebagai Faktor Resiko Utama Penyakit Jantung Koroner. CDK

Ramirez-Tortosa, M.C., Gloria U., Maria L.P., Teresa N., Maria C.G., Amalia M. et al., 1999. Extra Virgin Olive Oil Increases the Resistance of LDL to Oxidation More than Refined Olive Oil in Free Living Men with Peripheral Vascular Disease. Journal of Nutrition

Samuelson, G., Brattebv L.E., Mohsen R., Vessby B., 2001. Dietary Fat Intake in Healthy Adolescent: Inverse Relationships between the Estimated Intake of Saturated Fatty Acids and Serum Cholesterol. British Journal of Nutrition

Sharp, L., C.E.D. Chilvers, K.K. Cheng, P.A. McKinney, R.F.A. Logan, P. Cook-Mozaffari et al., 2001. Risk Factors for Squamous Cell Carcinoma of The Oesophagus in Woman: A Case Control Study. British Journal of Cancer

Sies, H., Wilhelm S., Alex S., 2005. Nutritional, Dietary and Postprandial Oxidative Stress. Journal of Nutrition

Toborek, M., Yong W.L., Rosario G., Simone K., Bernhard H., 2002. Unsaturated Fatty Acids Selectively Induce An Inflammatory Environment in Human Endothelial Cells. American Journal of Clinical Nutrition

Zhao, G., Terry D.E., Keith R.M., Sheila G.W., Peter J.G., Penny M.K., 2004. Dietary $\alpha$ Linolenic Acid Reduces Inflamatory and Lipid Cardiovascular Risk Factors in Hypercholesterolemic Men and Women. Journal of Nutrition 